\title{
Cinema e televisão: afastamentos e reaproximações na economia do audiovisual brasileiro contemporâneo
}

Gárdia Rodrigues Silva ${ }^{1}$

Resumo: No presente artigo, o olhar é direcionado para a configuração contemporânea da economia do audiovisual no cenário brasileiro. Para tanto, são observadas as relações entre cinema e televisão, delineadas ora por afastamentos, ora por reaproximações, e que, por sua vez, tecem esse contexto. Por fim, considerado o novo consórcio entre esses meios, alçado o audiovisual a setor da economia criativa, são analisados os contornos do surgimento do Fundo Setorial do Audiovisual (FSA) e da promulgação da Lei 12.485/11 (Lei da TV por Assinatura).

Palavras-chave: Economia do Audiovisual, Economia Criativa, Fundo Setorial do Audiovisual, Lei 12.485/11.

\begin{abstract}
On this article, the look is directed on the contemporary configuration of the audiovisual economy in the Brazilian scenario. To do that, the relationships between film and television are observed, sometimes outlined by spacings, sometimes by rapprochements, and that, in turn, weave this context. Finally, considering the new consortium between these means, raised the audiovisual sector of the creative economy, are analyzed the emerging contours of the Audiovisual Sector Fund (FSA) and the promulgation of Law 12.485/11 (Pay Television Law).
\end{abstract}

Keywords: Audiovisual Economy, Creative Economy, Audiovisual Sector Fund (FSA), Law 12.485/11.

\section{Introdução}

Aprovado pelo Conselho Superior de Cinema (CSC), em agosto de 2012, o Plano de Diretrizes e Metas para o Audiovisual (PDM), após consulta pública e nova apreciação pelo órgão em comento, tornou-se a referência para a política audiovisual brasileira, nos seguintes eixos: desenvolvimento da atividade audiovisual; produção e circulação de conteúdos brasileiros; economia sustentável, competitiva e inovadora; liberdade de criação e diversidade cultural. Para a inserção do audiovisual

${ }^{1}$ Mestranda do Programa de Pós-Graduação em Sociologia (PPGS) da Universidade Federal de Alagoas (UFAL).

Latitude, vol. 6, n², pp.267-295, 2012

DOI: https://doi.org/10.28998/2179-5428.20120210 


\section{Cinema e televisão: afastamentos e reaproximações na economia do audiovisual brasileiro contemporâneo}

brasileiro em um novo patamar de desenvolvimento, é prevista uma expansão do circuito cinematográfico, com a ampliação do número de filmes brasileiros lançados comercialmente, de 75 em 2010, para 170 em 2020; da renda bruta de bilheteria, de $\mathrm{R} \$ 1,26$ bilhão para $\mathrm{R} \$ 3,238$ bilhões, no mesmo período; da participação de filmes brasileiros nessas receitas, de 17,93\% para 30\%. Além disso, é prevista uma expansão dos serviços de TV por assinatura, com a ampliação do número de programadoras nacionais, de 6 para 20; de canais brasileiros nesse segmento de mercado, de 16 para 50; da participação de obras brasileiras independentes nas grades de programação, atingindo, até 2020, 41,3\%; entre outras diretrizes.

Essas perspectivas estão alinhadas com a centralidade do mercado audiovisual nas dinâmicas contemporâneas. Considerando matizes simbólicos, econômicos e culturais, o audiovisual vem sendo alçado à pauta da agenda governamental brasileira. Para a Secretaria do Audiovisual (SAV/MINC, 2012), é possível falar em uma revolução: "a revolução do conhecimento, da convergência, da inovação, da informação, da comunicação, da coletividade ou, simplesmente, a revolução criativa". Transformações sociais, econômicas, políticas e culturais ensejam redefinições de contextos e de conceitos. Novas práticas de consumo, inovações tecnológicas, profusão de mídias pautam a era da informação (CASTELLS, 1999), e requerem novos modelos de negócio, forjando outras configurações de mercado. Neste artigo, são observadas as nuances que atravessam esse importante campo de produção material e simbólica (BOURDIEU, 1992), sopesados os afastamentos e as reaproximações entre cinema e televisão na economia, que tece tal contexto. Nessa esteira, a partir das conexões entre cultura, criatividade e desenvolvimento, novos consórcios entre esses meios são alinhavados e, em tal conjuntura, merecem destaque dois importantes eventos: o lançamento do Fundo Setorial do Audiovisual (FSA) e a edição da Lei 12.485/11 (Lei da TV por Assinatura).

\section{O divórcio estético-político: cinema, televisão, negócio e cultura.}

Contornos traçados pela interação entre cinema e televisão demarcam a configuração contemporânea do campo audiovisual no Brasil. Para alcançar tal configuração, hierarquias e dicotomias, afastamentos e reaproximações, revelam as trajetórias desses meios audiovisuais, atravessadas pela função preponderantemente estética, atribuída ao cinema, e pela função comercial, pautada por controle e poder, atribuída à televisão. Ao percorrer essas trajetórias, é possível visualizar que o processo de instauração do cinema e da televisão, no Brasil, foi delineado por uma questão de viés nacionalista. Identidade brasileira, integração nacional, necessidade de incentivos estatais para a inserção de bases industriais, entre outros temas, norteiam discussões políticas, econômicas e 
culturais, assim como convalidam espaços para o cinema e para a televisão no país. Nos anos 1930, o direcionamento do olhar para o cinema brasileiro e para a correlata possibilidade de consolidação de uma identidade nacional estava em consonância com a ideia desenvolvimentista e nacionalista cunhada por Getúlio Vargas. Foi apresentado pelo governo um conjunto de diretrizes para o cinema, fundado, sobretudo, em incentivos para filmes de curta-metragem com fins educativos e de caráter nacionalista.

Naquele momento, o cinema foi percebido como estratégico para a formação e para a integração da nação. Em 1937, a articulação entre cinema, educação e nação foi intensificada pela criação do Instituto Nacional de Cinema Educativo (INCE), órgão vinculado ao Ministério da Educação (MEC). Ao valer-se do cinema como instrumento voltado para a formação da nacionalidade, o INCE atendia somente aos setores educativo e cultural, não havendo uma preocupação com o desenvolvimento de uma perspectiva industrial (Bahia, 2012). Essa preocupação aparece, efetivamente, nos anos 1940 e 1950. Com o fim desse governo, outras demarcações, tecidas pela instituição de um "capitalismo frágil e uma indústria cultural e um mercado de bens simbólicos incipientes" (idem, p. 33), e outras disputas, relativas à afirmação do cinema nacional perante o trânsito de filmes e a instalação de companhias distribuidoras norte-americanas nos mercados externos e, no caso em tela, no mercado brasileiro, assinalam o campo cinematográfico. Nesse período, duas importantes companhias cinematográficas brasileiras, com pretensões industriais e comerciais, apresentam impactos no mercado de cinema nacional, a saber, a Atlântida, criada em 1941, e a Vera Cruz, criada em 1949.

Apesar dos filmes produzidos entre os anos de 1951 a 1955 pelas companhias em comento, em média 27 ao ano, e da tentativa de construção de uma indústria e de um mercado de cinema nacional, estúdios e propostas entram em declínio. Lia Bahia (2012) aponta o estágio primitivo da industrialização, o surgimento da televisão, e a má administração de recursos como razões para tanto. Com distintos graus de modernização, ultrapassar a condição de subdesenvolvimento do cinema brasileiro representaria alcançar a própria modernização do país. Em meados dos anos 1950, a industrialização é repensada e novas propostas são esboçadas. Como aponta Pedro Butcher (2006), o setor cinematográfico, ao abarcar apenas a produção, não constrói uma base industrial consistente, e tanto sob a égide do governo de Getúlio Vargas, como do governo de Juscelino Kubitschek, o cinema não ultrapassa os âmbitos da Educação e da Cultura, respectivamente, para adentrar na seara econômica e industrial. Outrossim, diante das forças políticas e econômicas norte-americanas, o foco somente nesse elo da cadeia produtiva, garante uma posição confortável em relação aos Estados Unidos. Mas não só isso, também ensejou críticas a essa postura, proferidas por cineastas como Nelson Pereira dos Santos, Carlos Ortiz, Alex Viany, entre outros, fundadas na busca de uma produção repousada em uma 


\section{Cinema e televisão: afastamentos e reaproximações na economia do audiovisual brasileiro contemporâneo}

ideologia nacional popular. Para esses cineastas, por meio de temáticas e linguagens nacionais, atingir-se-ia a "verdadeira indústria" do cinema (Butcher, 2006). No início dos anos 1950, importantes eventos, como os Congressos de Cinema, foram realizados (1952 e 1953). Para além de questões sobre conquista de mercado, questões sobre formulação de uma política cinematográfica e questões sobre uma legislação para o setor também foram contempladas nos debates. Importa registrar a criação do Grupo de Estudos da Indústria Cinematográfica (GEIC), em 1956, e a criação do Grupo Executivo da Indústria Cinematográfica (GEICINE), em 1961. Este último situado no polo universalista/ industrialista por José Mario Ortiz Ramos (2004) e, portanto, implicado com a industrialização do cinema brasileiro. No outro polo, nacionalista/culturalista, o autor situa o Cinema Novo. Com influência da Nouvelle Vague francesa, e do neo-realismo italiano, o movimento cinemanovista, liderado por Glauber Rocha, propõe um afastamento da cinematografia orientada por perspectivas industrialistas. Trata-se de uma oposição entre o cinema industrial e o cinema de autoria: "se cabia a Hollywood fazer o cinema industrial, a única saída para o cinema brasileiro seria o cinema de autor" (BUTCHER, 2006, p. 34). Ao insurgir-se contra a indústria do cinema, ou, em outras palavras, contra a política defendida pelo GEICINE, o Cinema Novo propôs um novo modelo de fazer/conceber o cinema, e rejeitou padrões capitalistas. Para esse grupo, o subdesenvolvimento era uma condição a ser assumida, e o cinema nacional poderia ser um meio para refletir e construir suas próprias narrativas estéticas e políticas.

Foi nessa tessitura que emergiu o projeto de desenvolvimento do cinema brasileiro, reconhecido tanto pela via industrial, como pela via cultural. Com fulcro em uma visão desenvolvimentista, parte do setor cinematográfico, denominada "nacionalista", inclina-se para a realização de ações contra o monopólio do cinema norte-americano e, para além disso, busca ampla intervenção do governo nesse setor; outra parte, denominada "cosmopolita", inclina-se para a realização de filmes brasileiros aliados a filmes estrangeiros, e discorda da adoção de medidas inibitórias em relação à presença dos últimos filmes no país. Nessa trama, o cinema figura como questão estatal, e, em 1966, foi criado o Instituto Nacional de Cinema (INC), autarquia federal vinculada ao $\mathrm{Mec}$, que segue os moldes desenvolvimentistas do governo. Sendo assim, o cinema é inserido em uma política estatal de industrialização (Ortiz Ramos, 2004), e a impugnação do Cinema Novo, quanto ao modelo em voga foi ancorada na percepção desse meio como um bem de consumo. Havia uma preocupação do movimento cinemanovista com questões mercadológicas, mas principalmente quanto ao modo de instaurá-las. Industrialização e construção de um mercado de bens culturais são temas em pauta nos anos 1960 e 1970, e são qualificadas como "peças essenciais para alavancar o desenvolvimento do país" (Bahia, 2012, p. 46). É possível falar em uma tentativa de expansão de mercado aliada a uma atuação estatal. 
Ainda nesse registro, cumpre mencionar a introdução e a consolidação da televisão no país. Duas importantes emissoras, a TV Tupi (1950-1980) e a TV Excelsior (1960-1969), combinados a elementos políticos, econômicos e culturais, garantem o ingresso nesse cenário. Ao edificar uma estrutura assentada em uma organização industrial, a televisão, dotada de recursos/investimentos próprios, constrói uma trajetória independente do campo cinematográfico, e, embora ambos sejam relevantes para "difundir ideias, criar estados emocionais coletivos e legitimar o projeto de cultura nacional dentro de um processo de modernização do país" (Bahia, 2012, p. 47), recebem tratamentos estatais distintos. O Estado reconhece que cultura e meios audiovisuais envolvem relações de poder e vale-se disso para atuar junto a essas searas. Em um primeiro momento, mais especificamente, nos anos do pré-golpe de 1964, o Cinema Novo, conta com o apoio de alguns setores empresariais que aderem à visão nacionalista dominante. Após o Golpe e a decretação do Ato Institucional n. 5, em 1968, a repressão, a censura, e a absorção do discurso nacionalista pelo próprio regime, engendram a criação, em 1969, da Empresa Brasileira de Filmes S/A (Embrafilme). Com a criação dessa empresa de economia mista, o Estado ocupa um espaço central na produção e, posteriormente, na distribuição, de filmes brasileiros.

"Nacional como problema" é transformado em "nacional como mercadoria", com a construção de uma nova identidade, vinculada ao consumo e a determinados modos de vida (Butcher, 2006). No projeto cultural nacionalista, para a televisão, compreendida como "cultura de massa", é direcionado um alto investimento para a composição de uma infraestrutura de telecomunicações, sob a administração da iniciativa privada; já para o cinema, enquanto cultura popular e "artística", há a criação de órgãos estatais. Em palavras outras, resta a tutela estatal, desempenhada pela Embrafilme. Com a Embrafilme, e o Conselho Nacional de Cinema (Concine), criado em 1975, ocorreu um arranjo de políticas de incentivo com políticas de regulação. Ao olhar para as estatísticas relacionadas à produção cinematográfica nos tempos da Embrafilme, é possível observar elevados números, intensificada a produção ao longo dos anos 1970 e 1980. Na conjuntura exposta, de um lado, para a televisão, tem-se um empreendimento empresarial ancorado em um crescimento autônomo no que tange ao teor econômico, mas fortemente vinculado às estruturas políticas brasileiras; de outro, para o cinema, tem-se a Embrafilme como forma de ingerência do Estado sobre o setor em tela. Cumpre destacar que a perspectiva desse projeto impede movimentos de vinculação entre cinema e televisão e, por conseguinte, de formação de um campo audiovisual integrado. Televisão é assunto apenas de comunicação (BARBERO, 2003), e o cinema, cultura. Como se vê, hierarquias e dicotomias estruturam distintas políticas e trajetórias para o cinema e para a televisão. 


\section{Cinema e televisão: afastamentos e reaproximações na economia do audiovisual brasileiro contemporâneo}

\section{Crise e retomada do cinema nacional: reaproximação e estratégias}

Entre rupturas e continuidades, em consonância com vieses políticos, econômicos e culturais, a imbricação entre Estado e cinema, mediante regulações, incentivos e/ou subsídios, perpassa a historiografia do cinema brasileiro. A partir da Medida Provisória 151, de 15 de março de 1990, decretada por Fernando Collor de Mello, a dissolução de órgãos federais voltados ao cinema, como a Empresa Brasileira de Filmes S.A. (Embrafilme), o Conselho Nacional de Cinema (Concine), e a Fundação do Cinema Brasileiro (FCB), sem a substituição por outras estruturas, converge para a ausência de suporte estatal ao setor cinematográfico no país e, correlativamente, para a queda da produção de filmes. Falta de financiamentos; perda de mecanismos de proteção perante o cinema estrangeiro; desregulamentação da atividade; término da cota de tela; abertura irrestrita de importações; rompimento de contratos; paralisação de produções; entre outros fatores, demarcam, em um contexto específico, os contornos da crise da atividade cinematográfica e, em um contexto mais amplo, a desobrigação do Estado com a cultura no início dos anos 1990 (MARSON, 2009).

Diante de tal conjuntura, uma nova política de fomento, fundada em incentivos fiscais, assegurados pela Lei 8.313, de 23 de dezembro de 1991 (Lei Rouanet), destinada às atividades culturais, e pela Lei 8.685, de 20 de julho de 1993 (Lei do Audiovisual), destinada especificamente às atividades audiovisuais, engendrou a gradual retomada da cinematografia nacional. $\mathrm{O}$ advento dessas legislações, e de outras disposições, como as definições de cota de tela, de filme nacional e de coproduções internacionais, pela Lei 8.401, de 8 de janeiro de 1992, regulamentada pelo Decreto 567, de 11 de junho de 1992; a liberação de recursos da Embrafilme via Fundos de Investimentos Culturais e Artísticos (FICART), bem como a instituição da Comissão de Cinema para a seleção de filmes para financiamento, ambos nos termos do Decreto 575, de 23 de junho de 1992; a disponibilização desses recursos através do Prêmio Resgate do Cinema Brasileiro; o surgimento da Riofilme, importante distribuidora de filmes no cenário nacional; e a criação da Secretaria para o Desenvolvimento do Audiovisual, vinculada ao Ministério da Cultura (MINC), forjam o início de uma nova política cinematográfica.

É possível inferir que, a partir de meados dos anos 1990, durante o governo de Fernando Henrique Cardoso, o Estado retoma o "sentido da importância social, política e econômica da produção cinematográfica" (FORNAZARI, 2006, p. 650). Para além disso, com o aumento de filmes nacionais lançados comercialmente, e a volta do público às salas de cinema, como mostram os dados do quadro que segue abaixo; assim como com o emprego de técnicas, linguagens e estéticas advindas da publicidade e da televisão, e a elevação da qualidade das produções, não apenas o Estado, mas também a mídia, a sociedade e o próprio campo cinematográfico 
conferem prestígio, visibilidade e legitimidade ao cinema nacional. (BAHIA, 2012). Outrossim, frente à possibilidade de inserção dessa atividade em uma economia globalizada, e considerados os incentivos asseverados pelo Estado, o investimento em cinema nacional é percebido como "um negócio - e um bom negócio", e outros campos do audiovisual, como as produtoras O2 Filmes e Globo Filmes, direcionam o olhar para esse setor.

Tabela 1. Mercado de Cinema Brasileiro: 1995 - 1999.

\begin{tabular}{|c|c|c|c|c|c|}
\hline Ano & 1995 & 1996 & 1997 & 1998 & 1999 \\
\hline $\begin{array}{l}\text { Lançame } \\
\text { nto de filmes } \\
\text { nacionais }\end{array}$ & 12 & 22 & 22 & 26 & 33 \\
\hline $\begin{array}{l}\text { Público } \\
\text { de filmes } \\
\text { nacionais }\end{array}$ & $\begin{array}{l}2.966 .2 \\
39\end{array}$ & $\begin{array}{l}1.227 \\
.220\end{array}$ & $\begin{array}{l}2.401 .9 \\
59\end{array}$ & $\begin{array}{l}3.466 .2 \\
79\end{array}$ & $\begin{array}{l}5.715 \text {. } \\
914\end{array}$ \\
\hline
\end{tabular}

Fonte: Filme B, 2012.

Apesar desses avanços, não há a consolidação de um mercado de cinema brasileiro desvinculado do suporte estatal (Bahia, 2012). Os mecanismos previstos nas leis de incentivo são voltados para a produção cinematográfica, sem o aceno para uma articulação com os demais elos da cadeia produtiva - distribuição/ comercialização, exibição, e infraestrutura de serviços - e, por conseguinte, sem o aceno para uma atividade cinematográfica autossustentável. Da mesma forma, não obstante a aproximação entre o cinema, a publicidade e a televisão, nos moldes acima mencionados, não há uma vinculação comercial entre esses meios para a composição de um mercado audiovisual ou, em palavras outras, não é urdida uma política multimídia (CANCLINI, 2001). 


\section{Cinema e televisão: afastamentos e reaproximações na economia do audiovisual brasileiro contemporâneo}

Ainda, por meio da política de incentivos, é concedida à iniciativa privada não apenas a dedução do imposto de renda dos valores investidos em projetos culturais, mas também o poder de deliberação sobre os projetos exequíveis, o que conduz a uma "administração privada de recursos públicos" (BUTCHER, 2005, p. 19), e a um deslocamento da "gerência da cultura para a iniciativa privada" (Bahia, 2012, p. 61). No final dos anos 1990, esses e outros fatores, como, por exemplo, denúncias de irregularidades no uso desses mecanismos, fundamentam as reivindicações do setor cinematográfico no que tange à reorganização do mercado e à reorientação das políticas públicas para o cinema. Frente a esse contexto, merece referência o III Congresso Brasileiro de Cinema (CBC), realizado em junho de 2000, em Porto Alegre - RS. Com a presença de entidades e representantes de distintos segmentos do setor, esse evento, organizado pela Fundação Cinema RS (Fundacine), e presidido pelo cineasta Gustavo Dahl, demarca a busca pela reestruturação e repolitização do cinema brasileiro. A partir desse Congresso, com fulcro no entrelaçamento entre cultura, política e economia, o Estado reconhece a necessidade de um novo delineamento para a relação Estado/cinema, e elege a integração entre os meios audiovisuais, sobretudo entre o cinema e a televisão, como um eixo estratégico para a consolidação de uma indústria audiovisual autossustentável e, nesse rumo, conta com a anuência do próprio campo cinematográfico, apesar da cisão de longa data entre um setor marcado pela autonomia cultural e artística e outro pela pretensão industrial e comercial (Ortiz Ramos, 2004). Para tanto, foi criado o Grupo Executivo para o Desenvolvimento da Indústria Cinematográfica (GEDIC), que, ao mesclar orientações culturais e econômicas, elenca cinco propostas para a inserção do cinema em um mercado global, quais sejam, a criação de um órgão institucional para a atividade cinematográfica; a redefinição das funções da Secretaria do Audiovisual (SAV); a criação de um fundo de fomento para o desenvolvimento da cadeia produtiva; a reformulação das legislações existentes e a disposição de uma legislação para a regulação do sistema televisivo. Dessas propostas, de acordo com a tentativa de alçar o cinema nacional a outro patamar de desenvolvimento, emerge a Medida Provisória 2.228-1, de 6 de setembro de 2001, com adendos da Lei 10.454, de 13 de maio de 2002. A aludida medida, além de criar a Agência Nacional do Cinema (ANCINE), contempla as diretrizes para a Política Nacional do Cinema (PNC); define obra audiovisual brasileira; cria o Conselho Superior do Cinema (CSC); e versa sobre alguns mecanismos fiscais².

2 Contribuição para o Desenvolvimento da Indústria Cinematográfica Nacional (CONDECINE); Fundos de Financiamento da Indústria Cinematográfica Nacional (Funcines); Programa de Apoio ao Desenvolvimento do Cinema Nacional (PRODECINE); e conversão da dívida externa em projetos de produção, distribuição, exibição e divulgação de obras audiovisuais brasileiras, de acordo com o inciso V, do Artigo $1^{\circ}$, da Lei 10.179, de 6 de fevereiro de 2001. 
A publicação da medida em tela é uma tentativa de rearticulação das ações governamentais e, a partir dela, uma nova institucionalidade é concebida para o cinema brasileiro, ancorada na complementaridade de três órgãos estatais: o CSC, voltado à formulação da política nacional do cinema; a ANCINE, voltada ao fomento, regulação e fiscalização da indústria cinematográfica; e a SAV, voltada à assessoria, elaboração e execução de políticas, planos e diretrizes. A complementariedade entre esses órgãos fundar-se-ia nas distintas vinculações de cada um deles, o CSC enquanto órgão superior, e portanto de instância supraministerial, ficaria sob a égide da Casa Civil, ligada diretamente à Presidência da República; a ANCINE, por tratar de aspectos do "cinema industrial", ficaria sob a égide do Ministério do Desenvolvimento, Indústria e Comércio Exterior (MDIC); e a SAV, por tratar de aspectos do "cinema cultural", ficaria sob a égide do Ministério da Cultura (MINC). Paulatinamente, com o governo de Luiz Inácio Lula da Silva, há um rompimento desse tripé institucional e, atualmente, os três órgãos estão vinculados ao MINC (Ikeda, 2012). Esses novos parâmetros levam a um significativo aumento de filmes nacionais lançados comercialmente: de 20 a 30 filmes anuais lançados até 2003, a produção foi elevada para mais de 40 filmes nos anos seguintes, como se vê abaixo.

Tabela 2. Mercado de Cinema Brasileiro: 2000 - 2007.

\begin{tabular}{|c|c|c|c|c|c|c|c|c|}
\hline Ano & 2 & 2 & 2 & 2 & 20 & 20 & 20 & 2 \\
\hline & 000 & 001 & 002 & 003 & 04 & 05 & 06 & 007 \\
\hline $\begin{array}{l}\text { Lança } \\
\text { mento de } \\
\text { filmes } \\
\text { nacionais }\end{array}$ & $3^{2}$ & $0^{3}$ & $9^{2}$ & $0^{3}$ & 49 & 44 & 73 & $8^{7}$ \\
\hline $\begin{array}{l}\text { Públi } \\
\text { co }\end{array}$ & 6 & 7 & 7 & 2 & 15 & 10 & 10 & 9 \\
\hline $\begin{array}{l}\text { de } \\
\text { filmes }\end{array}$ & $\begin{array}{c}.344 .66 \\
9\end{array}$ & $\begin{array}{c}.948 .06 \\
5\end{array}$ & $\begin{array}{c}.170 .33 \\
4\end{array}$ & $\begin{array}{c}2.291 .80 \\
6\end{array}$ & .494 .873 & .178.304 & .727 .571 & $\begin{array}{c}.112 .93 \\
4\end{array}$ \\
\hline
\end{tabular}

Fonte: ANCINE, 2012.

Apesar do alcance de público e de filmes lançados, e embora atendidas diversas requisições do campo cinematográfico, a regulação televisiva e a integração entre cinema e televisão não foram abarcadas pela legislação. Ainda que 


\section{Cinema e televisão: afastamentos e reaproximações na economia do audiovisual brasileiro contemporâneo}

exista um dispositivo na Medida Provisória 2.228-1/01, mais especificamente o Artigo 39, dedicado à programação internacional, e referente à opção de aplicação do valor correspondente a $3 \%$ do pagamento da Contribuição para o Desenvolvimento da Indústria Cinematográfica Nacional (CONDECINE) em produção nacional para cinema e televisão, trata-se de um dispositivo isolado, não remete à integração em questão. Caberia à ANCINE não somente fomentar e regular o conteúdo para cinema, mas também o conteúdo para televisão, entretanto, os itens televisivos são excluídos do texto final da Medida. De agência do audiovisual, a ANCINE é reduzida à agência do cinema. Via política estatal, disputas, negociações, reivindicações e pressões que circunscrevem esses meios adiam o trânsito do cinema pela cultura da mídia (Kellner, 2001). Todavia, essa articulação é realizada via política privada, com a criação do departamento de cinema da Rede Globo, a Globo Filmes.

Ao longo dos anos, não há investimentos em produções filmográficas, assim como não há uma inserção significativa de filmes brasileiros na grade de programação dessa emissora firmada como hegemônica no país. No entanto, a partir do fim dos anos 1990, a criação da Globo Filmes, demarcou uma nova relação entre cinema e televisão. A aproximação estratégica desses meios está ancorada nos desafios econômicos e estruturais acarretados pelas transformações tecnológicas das últimas décadas do século XX. Novas tecnologias - internet, celulares, TV paga, TV digital - acenam para novas demandas por conteúdo audiovisual e novas possibilidades de produção e difusão da informação. Em prol da defesa do conteúdo nacional, da ampliação e da manutenção de legitimidade da emissora, e da antecipação de respostas às revisões da legislação audiovisual desenhada a partir dos governos de Fernando Henrique Cardoso e de Luis Inácio Lula da Silva, a TV Globo direciona o olhar para esse setor. No âmbito estatal, entre avanços e recuos, para suprir essas ausências, em abril de 2004, foi apresentada ao Congresso Nacional a minuta de um projeto de lei que criaria a Agência Nacional do Cinema e do Audiovisual (ANCINAV); essa agência, além de substituir a ANCINE, teria a competência para fiscalizar e regular o cinema, as TVs Abertas e por Assinatura, o rádio e os demais meios audiovisuais. Novas disputas, negociações, reivindicações e pressões encerram abortaram projeto.

No Brasil, enquanto o desenvolvimento da televisão é marcado por um negócio híbrido, entre o público e o privado, o desenvolvimento do cinema é marcado pela dependência de políticas estatais. Considerando o processo de modernização do país, essa construção reporta a distinções e dicotomias conferidas a esses meios ao longo dos anos. Indústria/entretenimento e negócio empresarial/comercial refletem o tratamento conferido à televisão; já o artístico/cultural e a política estatal, refletem o tratamento conferido ao cinema (BAHIA, 2012). Nos anos recentes, uma reorganização do campo cultural e, por extensão, do campo audiovisual, é alinhavada. Novos discursos, políticas e/ou 
práticas enfraquecem essas oposições e hierarquias, e acenam para a aproximação entre o cinema e a televisão. Na composição deste novo arranjo, importantes medidas são adotadas para a consolidação de um mercado audiovisual e, nessa contextura, estão inseridos o lançamento do Fundo Setorial do Audiovisual (FSA), em 2008, e a edição da Lei 12.485 (Lei da TV por Assinatura), em 2011.

4. O audiovisual como setor da economia criativa: cultura, criatividade e desenvolvimento - o novo consórcio televisão e cinema.

Nos tempos contemporâneos, instituições internacionais como a Organização das Nações Unidas (ONU), através de suas agências de cooperação Conferência das Nações Unidas para o Comércio e o Desenvolvimento (UNCTAD), Programa das Nações Unidas para o Desenvolvimento (PNUD), Organização das Nações Unidas para a Educação, a Ciência e a Cultura (UNESCO), entre outras, bem como o Estado brasileiro, lançam um novo olhar para a cultura, e passam a percebê-la como um eixo estratégico para o desenvolvimento. No contexto brasileiro, esse novo olhar é peremptório para uma reconfiguração econômico-cultural (ORTIZ, 2008), e nele, "criatividade e diversidade, $[. .$.$] se entrelaçam e se resolvem num conjunto único de cultura". { }^{3}$ Criatividade, orientada pela singularidade, pelo simbólico, pelo intangível, que remete à "capacidade não só de criar o novo, mas de reinventar, diluir paradigmas tradicionais, unir pontos aparentemente desconexos e, com isso, equacionar soluções para novos e velhos problemas" (Reis, 2008, p. 15), e diversidade, nos termos da Convenção sobre a Proteção e Promoção da Diversidade das Expressões Culturais, adotada em outubro de 2005, durante a 33 $3^{\text {a }}$ Conferência Geral da UNESCO e aprovada, no âmbito brasileiro, pelo Decreto Legislativo 485, de 20 de dezembro de 2006.

Esses novos delineamentos para cultura e desenvolvimento restam recepcionados pelo Plano Nacional de Cultura - PNC, instituído pela Lei 12.343, de 2 de dezembro de 2010, nos termos do $\S 3^{\circ}$ do artigo 215, da Constituição Federal de 1988. Depreende-se de tal Plano que resta reafirmada uma concepção ampliada de cultura, consideradas as suas dimensões simbólica, no que tange à valorização e à consolidação da identidade nacional, assim como ao acesso a bens e equipamentos culturais; cidadã, no que tange à efetivação dos direitos culturais, assegurados constitucionalmente; e econômica, no que tange à geração de emprego e renda por meio de atividades culturais. $\mathrm{O}$ encadeamento dessas dimensões passa a nortear programas, projetos e políticas culturais no país, em busca de um

${ }^{3}$ Disponível em http://www.cultura.gov.br/site/2011/01/03/discurso-de-posse-da-ministrada-cultura-ana-de-hollanda/ Acesso em Junho de 2012.

Latitude, vol. 6, $\mathrm{n}^{\circ} 2$, pp.267-295, 2012 


\section{Cinema e televisão: afastamentos e reaproximações na economia do audiovisual brasileiro contemporâneo}

desenvolvimento orientado pela diversidade cultural, inclusão social, inovação e sustentabilidade, como anuncia o PNC.

Dinâmicas culturais, sociais e econômicas erigidas a partir de bens e serviços oriundos de setores criativos, demarcados pelo viés simbólico, intangível, fundamentam a ideia de economia criativa. Em palavras outras, a imbricação entre cultura e desenvolvimento implica em novos usos dessas categorias, e seus desdobramentos convergem para a concepção de economia criativa. A economia criativa, construção simbólico-discursiva tecida nas décadas finais do século $\mathrm{XX}$, a partir de discursos de organismos como a UNESCO, em âmbito transnacional, e como o MINC, em âmbito nacional, emerge em um contexto de industrialização do simbólico (CANCLINI, 1990), de expansão dos serviços e bens culturais e de crescimento da importância a eles atribuídas ou, em suma, do significativo aumento dos mercados culturais, e em meio às novas relações entre arte, técnica e memória (ALVES, 2011). Essa economia é um dos setores mais dinâmicos da economia global (MIQUEZ, 2007), pois instaura novas realidades e consigna novas dinâmicas econômico-culturais.

Em uma conjuntura de proliferação de telas, há "tela em todo lugar e a todo momento. Tela de vídeo, tela em miniatura, tela gráfica, tela nômade, tela táctil: o século que começa é o da tela onipresente e multiforme, planetária e multimídia" (LIPOVETSKY; SERROY, 2009, p. 23). Nesse período do "tudo-tela", marcado pela inventividade, diversidade e vitalidade, e pelas novas tecnologias da informação e da comunicação ou, em outros termos, pelas convergências que definem "transformações tecnológicas, mercadológicas, culturais e sociais" (JENIKIS, 2008, p. 22), merece destaque a "tela-ecrâ". As transformações contemporâneas envolvem em um movimento "as tecnologias e os meios de comunicação, a economia e a cultura, o consumo e a estética", e o "cinema obedece à mesma dinâmica" (LIPOVETSKY; SERROY, 2009, p. 23). Considerando o processo de interdependência e complementaridade entre os meios que compõem o campo audiovisual (Bahia, 2012), bem como a incorporação de uma ampla noção de cultura, outras modalidades de bens simbólicos, como a televisão, são incluídas no âmbito de atuação do governo (Bezerra; Rocha, 2012). Com o advento do Fundo Setorial do Audiovisual (FSA) e a edição da Lei 12.485, de 12 de setembro de 2011 Lei da TV por assinatura, há uma aproximação inédita entre o cinema e a televisão. Instituído pela Lei 11.437, de 28 de dezembro de 2006, regulamentado pelo Decreto 6.299, de 12 de dezembro de 2007, e lançado em 04 de dezembro de 2008, pelo Ministro da Cultura à época - Juca Ferreira, e pelo Diretor Presidente da ANCINE - Manoel Rangel, o Fundo Setorial do Audiovisual (FSA) é a primeira categoria de programação específica do Fundo Nacional de Cultura (FNC) posta em operação. Com o fim de fomentar o desenvolvimento articulado da atividade audiovisual brasileira, distintos instrumentos, como investimentos, financiamentos, operações de apoio e de equalização de encargos financeiros são 
endereçados aos diversos elos da cadeia produtiva: produção, distribuição/comercialização, exibição, e infraestrutura de serviços. Em cotejo com outros investimentos públicos para a cultura no país, o FSA apresenta nova abrangência de atuação e novos meios de estímulo estatal ao setor audiovisual. Para Manoel Rangel, esse fundo incute "um novo ciclo de desenvolvimento para a economia do cinema e do audiovisual no Brasil"; representa "uma possibilidade de ação sistêmica inédita e necessária" nessa seara (ANCINE, 2012).

Com receitas oriundas da própria atividade econômica, de contribuições recolhidas pelos agentes de mercado, sobretudo da Contribuição para o Desenvolvimento da Indústria Cinematográfica Nacional (CONDECINE), e do Fundo de Fiscalização das Telecomunicações (FISTEL), entre outras fontes, cabe ao FSA apoiar o desenvolvimento de alguns programas, a saber, o Programa de Apoio ao Desenvolvimento do Cinema Brasileiro (PRODECINE); o Programa de Apoio ao Desenvolvimento do Audiovisual Brasileiro (PRODAV); e o Programa de Apoio ao Desenvolvimento da Infraestrutura do Cinema e do Audiovisual (Próinfra), de acordo com o Artigo 4, da Lei 11.437/06, combinado com o Artigo 47, da Medida Provisória 2.228-1/01. Nessa senda, compete ao FSA operar por meio de editais públicos, a partir de quatro linhas iniciais de atuação - produção cinematográfica, produção para televisão, aquisição de direitos de distribuição cinematográfica e comercialização de obras cinematográficas -, dispostas na modalidade de investimento e, portanto, com comprometimento comercial das obras, risco ausente nos financiamentos públicos desde a extinção da EMBRAFILME.

Chamadas públicas instauraram as seleções de projetos para financiamento pelo FSA, que são realizadas através de concurso público ou por fluxo contínuo. $\mathrm{Na}$ modalidade de fluxo contínuo, antiga requisição do setor audiovisual para atender às dinâmicas da cadeia produtiva, os investimentos são estendidos para períodos posteriores à época de lançamento do edital. Em outros termos, a apresentação de projetos pode ser feita a qualquer tempo, considerada a data de convocação da linha de ação. No tocante aos projetos, as propostas podem ser expostas por empresas brasileiras independentes, registradas na ANCINE e nas Juntas Comerciais. A essas propostas são atribuídas notas e sopesados alguns quesitos, conforme a linha de ação ${ }^{4}$. Além dessas notas, são atribuídas pontuações relativas ao retorno financeiro de investimentos anteriormente realizados pelo Fundo em projetos da empresa ora proponente, sendo negativas as avaliações quando não alcançado o montante referente à recuperação prioritária, também denominada de retorno mínimo. A alíquota, para fins desse retorno, incide sobre a

${ }^{4}$ Aspectos artísticos e adequação ao público; qualificação de diretor, roteirista e elenco; capacidade gerencial e desempenho de produtora ou distribuidora; e planejamento e adequação do plano de negócios figuram entre os quesitos. 


\section{Cinema e televisão: afastamentos e reaproximações na economia do audiovisual brasileiro contemporâneo}

Receita Líquida do Produtor (RLP), auferida sobre segmentos de mercado e janelas de exploração, licenciamento de marcas e imagens, e contratos de transferência de direitos patrimoniais da obra e derivados (ANCINE, 2012).

Com essa nova política setorial, são considerados os desempenhos precedentes das empresas, assim como o potencial de mercado dos projetos. Sendo assim, ao dispor de recursos reembolsáveis e participar dos direitos de comercialização das obras, o governo atua como sócio das empresas. Vânia Catani, produtora da Bananeira Filmes, e uma das primeiras contempladas pelas Chamadas Públicas do FSA, faz referência a um novo momento para o setor audiovisual: "todos nós que atuamos como produtores durante a Retomada tivemos que ser convertidos em empresários, de modo que essa nova equação de equilíbrio é o desafio" (Filme B, 2012). Para Manoel Rangel, uma política sustentável de ocupação do mercado exige uma alteração nos pressupostos de financiamento. Em números, no quadro abaixo, seguem os projetos inscritos, habilitados e contemplados nas quatro linhas de ação, nos anos 2008, 2009 e 2010. 
Tabela 3. Projetos por Linhas de Ação: 2008 - 2010.

\begin{tabular}{|c|c|c|c|c|c|c|}
\hline & \multicolumn{6}{|c|}{ Chamadas Públicas } \\
\hline no & $\begin{array}{l}\text { Linhas } \\
\text { de } \\
\text { Ação }\end{array}$ & $\begin{array}{l}\text { Linha A } \\
\text { Produção } \\
\text { Cinemato } \\
\text { gráfica }\end{array}$ & 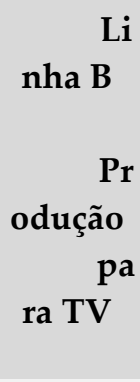 & $\begin{array}{l}\text { Lin } \\
\text { ha C } \\
\text { Aq } \\
\text { uisição } \\
\text { de } \\
\text { Dir } \\
\text { eitos }\end{array}$ & $\begin{array}{l}\text { Linha D } \\
\text { Comercia } \\
\text { lização }\end{array}$ & otal \\
\hline \multirow{3}{*}{008} & $\begin{array}{l}\text { Inscrito } \\
\mathrm{s}\end{array}$ & 220 & 46 & 15 & 18 & 97 \\
\hline & $\begin{array}{l}\text { Habilit } \\
\text { ados }\end{array}$ & 144 & 24 & 10 & 12 & 90 \\
\hline & $\begin{array}{l}\text { Conte } \\
\text { mplados }\end{array}$ & 18 & 5 & 8 & 7 & 8 \\
\hline \multirow{3}{*}{009} & $\begin{array}{l}\text { Inscrito } \\
\mathrm{s}\end{array}$ & 207 & 57 & 26 & 12 & 02 \\
\hline & $\begin{array}{l}\text { Habilit } \\
\text { ados }\end{array}$ & 191 & 39 & 22 & 12 & 64 \\
\hline & $\begin{array}{l}\text { Conte } \\
\text { mplados }\end{array}$ & 45 & 23 & 16 & 10 & 4 \\
\hline \multirow{3}{*}{010} & $\begin{array}{l}\text { Inscrito } \\
\mathrm{s}\end{array}$ & 189 & 57 & 24 & 4 & 74 \\
\hline & $\begin{array}{l}\text { Habilit } \\
\text { ados }\end{array}$ & 174 & 41 & 23 & 4 & 42 \\
\hline & $\begin{array}{l}\text { Conte } \\
\text { mplados }\end{array}$ & 41 & 21 & 16 & 2 & 0 \\
\hline
\end{tabular}

Latitude, vol. 6, n², pp.267-295, 2012 


\section{Cinema e televisão: afastamentos e reaproximações na economia do audiovisual brasileiro contemporâneo}

Fonte: ANCINE, Finep, 2012.

Após longo período de financiamentos públicos fundados em mecanismos de incentivos fiscais, não obstante a recuperação da produção cinematográfica no país, para a efetiva inserção do cinema nacional no mercado audiovisual, outra política cultural, mais consistente e abrangente, vem sendo vislumbrada com a instauração do FSA (BAHIA, 2012). A eficácia dessa política depende de uma lógica mais ampla, para além da produção de filmes de longa-metragem, requer o direcionamento do olhar para a complexa e dinâmica rede de relações que envolvem a cadeia produtiva do audiovisual (MATTA, 2010). Ao aferir os projetos selecionados pelas linhas de ação, apesar de contemplados os distintos elos dessa cadeia, assim como diversos gêneros e empresas, depreende-se que há a concentração de projetos oriundos da Região Sudeste, mais especificamente dos estados do Rio de Janeiro e de São Paulo. Esmiuçando os dados mostrados no quadro anterior, do total de projetos contemplados, 106 são procedentes do Rio de Janeiro; 80, de São Paulo, e 24, de outros Estados 5 .

\footnotetext{
${ }^{5}$ Destes 24 projetos, 9 são procedentes do Rio Grande do Sul, 6 do Paraná, 5 da Bahia, 3 do Distrito Federal e de Minas Gerais, e 1 do Ceará, da Paraíba, e de Pernambuco. Em relação à comercialização desses projetos, os números são 27,9 e 3, consideradas as Linhas $\mathrm{A}, \mathrm{C}$ e D, respectivamente. Da Linha A, foram comercializados: Besouro; Do Começo ao Fim; Histórias de amor duram apenas 90 minutos; Insolação; Chico Xavier; Eu e Meu GuardaChuva; Bruna Surfistinha; Estamos Juntos; Não se Preocupe, Nada Vai dar Certo; Transeunte; Onde Está a Felicidade?; O Homem do Futuro; Capitães da Areia; Meu País; As Aventuras de Agamenon, o repórter; Billi Pig; Xingu; Eu receberia as piores notícias dos seus lindos lábios; O Homem Que Não Dormia; Histórias que só existem quando lembradas; Febre do Rato; Beira do Caminho; Cara ou Coroa; Boca; Gonzaga - De pai para filho; O país do desejo; Os Penetras; da Linha C: Cinco Vezes Favela; De pernas pro ar; Desenrola; Cilada.com; O Palhaço; Billi Pig; E Ai, Comeu?; Totalmente Inocentes; Até que a Sorte nos Separe; e, da Linha D: Quebradeiras; Corações Sujos; Onde a coruja dorme.
} 
Tabela 5. Projetos contemplados por estados: $2008-2010$.

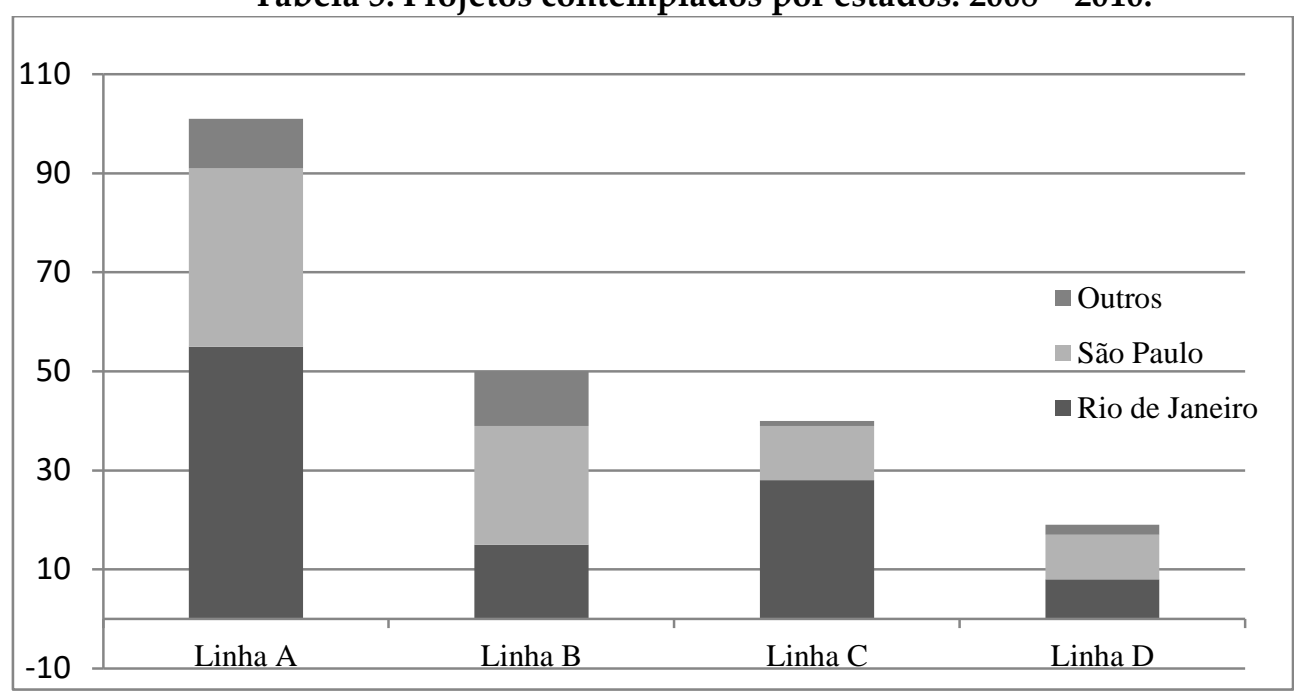

Fonte: ANCINE, 2012.

Com a promulgação da Lei $12.485,{ }^{6}$ sancionada pela Presidente Dilma Rousseff, em setembro de 2011, resultado de longa tramitação no Congresso Nacional, e de intensos diálogos e negociações entre parlamentares, representantes do setor audiovisual, agentes econômicos e representantes da sociedade civil, novos contornos são traçados para a cadeia produtiva do setor audiovisual no país e, nessa tessitura, outras abrangências e recursos para o FSA. Convergência de mídias, transformações tecnológicas, novos modos de consumo de informação e de conteúdo audiovisual postulam novos delineamentos normativos. Em um cenário marcado pelo aumento das demandas dos serviços de TV por Assinatura, e pela imbricação entre economia criativa, economia do audiovisual e economia da informação, a Lei 12.485 figura como um marco regulatório para a comunicação audiovisual.

Considerando os avanços trazidos pelo texto legislativo, três grandes inovações merecem destaque, quais sejam: a unificação de tecnologias, a obrigatoriedade de cotas de conteúdo brasileiro e independente nas programações das TVs por Assinatura e o ingresso de novos agentes econômicos nesse mercado.

\footnotetext{
${ }^{6}$ São finalidades desta Lei: aumentar a competitividade e a garantia da sustentabilidade do setor audiovisual; ampliar o acesso às obras audiovisuais brasileiras e aos canais brasileiros de programação; induzir a sustentabilidade das produtoras e das programadoras brasileiras independentes, através da geração de receitas provenientes das atividades de produção e de programação, resguardada a detenção do poder dirigente sobre o patrimônio da obra; promover ampla, livre e justa competição, estendendo a oferta de serviços e estimulando a redução do preço final ao assinante; estimular o aumento da produção e da veiculação de obras audiovisuais que promovam a diversidade cultural brasileira; entre outras.
} 


\section{Cinema e televisão: afastamentos e reaproximações na economia do audiovisual brasileiro contemporâneo}

A partir dessas inovações, novos recursos são destinados ao setor audiovisual, mais especificamente ao FSA. Estes novos recursos advém da arrecadação da nova Contribuição para o Desenvolvimento da Indústria Cinematográfica Nacional (CONDECINE). Com a promulgação da Lei 12.485, a CONDECINE é estendida às concessionárias, permissionárias e autorizadas de serviços de telecomunicações que possam, efetiva ou potencialmente, distribuir conteúdos audiovisuais, de acordo com a redação dada pelo Artigo 26, dessa lei, ao inciso II, do Artigo 32, da MP 2.228-1/01. Outrossim, ao instituir outra redação ao Artigo 4 da Lei 11.437/06, o Artigo 27 da Lei da TV por Assinatura determina que, dos recursos advindos da nova CONDECINE, no mínimo 30\% devem ser reservados a produtoras brasileiras situadas nas regiões Norte, Nordeste e Centro-Oeste e, no mínimo, 10\% devem ser reservados ao fomento de produções audiovisuais independentes, com veiculação prioritária em canais comunitários, universitários e de programadoras brasileiras independentes.

Essas novas destinações estão alinhadas com os princípios informadores da comunicação audiovisual de acesso condicionado. Dentre esses princípios, vale sublinhar a promoção da diversidade cultural e das fontes de informação, produção e programação, assim como o estímulo à produção independente e regional. Igualmente, nos termos do Parágrafo Único, do Artigo 3 dessa lei, vale realçar o aditamento de outros princípios, nomeadamente aqueles constantes na Convenção sobre a Proteção e Promoção da Diversidade das Expressões Culturais. Cabe registro a consonância normativa da Lei 12.485 com o valor adjudicado à diversidade cultural enquanto uma "referência maior na busca de um novo ordenamento" (MATTELART, 2005, p. 133). Com a Lei 12.485 e com o FSA, há uma redefinição dos fundamentos do financiamento público para o setor audiovisual. Um dessas redefinições está relacionada à abrangência dos serviços. É estimado em $\mathrm{R} \$ 400$ milhões anuais o volume adicional de recursos para o mercado audiovisual, consideradas, em conformidade com a lei, as novas operações para televisão, cinema e outras mídias. O montante mencionado representa o quádruplo dos recursos atualmente disponíveis no FSA, assim como supera os valores captados via mecanismos de incentivo para o setor. A seguir, são exibidos os valores dos investimentos em audiovisual entre os anos de 2007 a 2011, assim como os valores investidos em cada linha de ação do FSA. 
Tabela 6. Investimentos em Audiovisual: 2007 - 2011 (R\$).

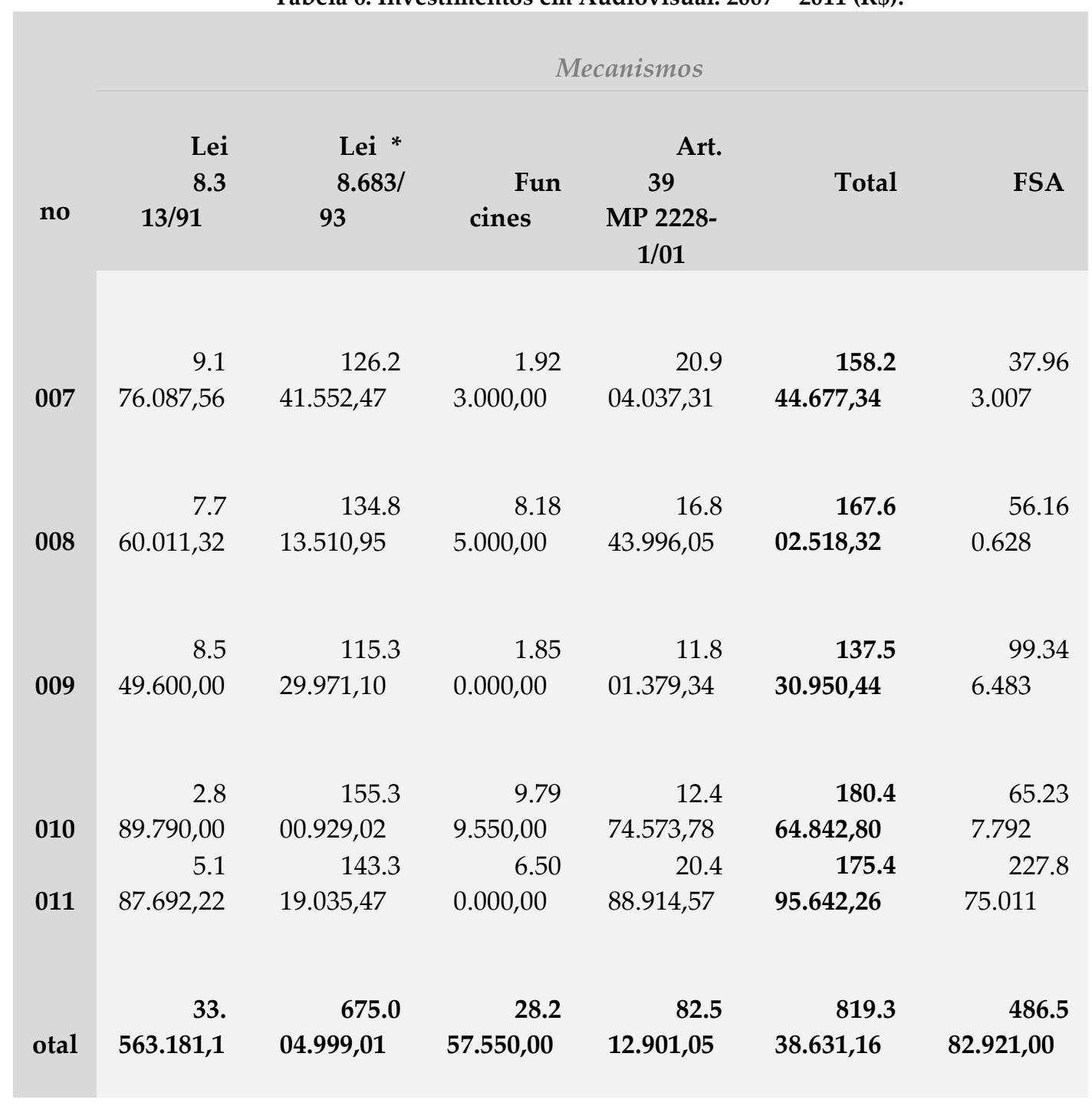

Fonte: ANCINE, 2012.

* Inclusos os incentivos referentes aos Artigos $1^{\mathrm{o}}, 1^{\mathrm{o}} \mathrm{A}, 3^{\circ}$ e $3^{\mathrm{o}} \mathrm{A}$. 
Cinema e televisão: afastamentos e reaproximações na economia do audiovisual brasileiro contemporâneo

Tabela 7. Recursos disponibilizados pelo FSA: 2008 - 2012 (R\$).

\begin{tabular}{|c|c|c|c|c|c|}
\hline & & & Linhas & le Ação & \\
\hline no & $\begin{array}{c}\text { A: } \\
\text { Produção } \\
\text { Cinematográfic } \\
\text { a }\end{array}$ & $\begin{array}{c}\text { B: } \\
\text { Produção } \\
\text { par } \\
\text { a TV }\end{array}$ & $\begin{array}{l}\qquad \text { C: } \\
\text { Aquisição } \\
\text { de } \\
\text { Direitos }\end{array}$ & $\begin{array}{l}\text { D:Comercializaçã } \\
\text { o }\end{array}$ & $1^{\text {Tota }}$ \\
\hline 008 & 15.000 .000 & $\begin{array}{r}7.0 \\
00.000\end{array}$ & $\begin{array}{r}10.0 \\
00.000\end{array}$ & 5.000 .000 & $\begin{array}{r}37.0 \\
00.000\end{array}$ \\
\hline 009 & 33.757 .261 & $\begin{array}{r}17 . \\
757.261\end{array}$ & $\begin{array}{r}22.5 \\
00.000\end{array}$ & 7.500 .000 & $\begin{array}{r}81.5 \\
14.522\end{array}$ \\
\hline 010 & 38.000 .000 & $\begin{array}{r}20 . \\
000.000\end{array}$ & $\begin{array}{r}25.0 \\
00.000\end{array}$ & 5.000 .000 & $\begin{array}{r}88.0 \\
00.000\end{array}$ \\
\hline 012 & 90.000 .000 & $\begin{array}{r}55 . \\
000.000\end{array}$ & $\begin{array}{r}50.0 \\
00.000\end{array}$ & 10.000 .000 & $\begin{array}{r}205 . \\
000.000\end{array}$ \\
\hline otal & $\begin{array}{c}176.757 .26 \\
1\end{array}$ & $\begin{array}{r}99 . \\
757.261\end{array}$ & $\begin{array}{r}107 . \\
500.000\end{array}$ & 27.500 .00 & $\begin{array}{r}411 . \\
514.522\end{array}$ \\
\hline
\end{tabular}

Fonte: ANCINE, 2013.

Em 2012, o orçamento do FSA corresponde a R\$109.760.348 e, com o crédito suplementar de R 400 milhões, perfaz um total de mais de R 500 milhões, ou seja, perfaz um montante superior à soma do orçamento total do FSA, considerados os 
anos anteriores, de 2007 a 2011. Frente ao aumento de recursos e demandas audiovisuais, decorrentes das inovações engendradas pela Lei 12.485, mediante contrato firmado pela ANCINE, Secretária-Executiva do FSA, e a partir de indicação do Comitê Gestor (CGFSA) - formado por dois representantes do MINC, um representante da ANCINE, um dos agentes financeiros credenciados e dois representantes do setor audiovisual -, o Fundo está sob os auspícios do Banco Nacional de Desenvolvimento Econômico e Social (BNDES). Como declara Manoel Rangel, essa escolha é ancorada na "expertise na administração de mecanismos financeiros" apresentada pelo BNDES ao longo dos anos (ANCINE, 2012). Outrossim, a referida escolha reflete o entrelaçamento entre agentes econômicos e agentes culturais no campo cultural contemporâneo. O viés dinâmico das atividades econômicas referentes à cultura, e a consequente expansão do mercado de bens culturais, motiva agentes econômicos, como o BNDES, a direcionar o olhar para a seara cultural.

Nesses termos, dada a relevância econômica e o potencial de crescimento desse setor, em 2006 a economia da cultura foi incorporada à estrutura operacional do BNDES. Em um primeiro momento, com o enfoque no setor audiovisual e nos elos produtivos correlatos, e foi lançado o Programa de Apoio à Cadeia Produtiva do Audiovisual (PROCULT). Para atender a esse recorte setorial, "soluções criativas" são tecidas através do "uso articulado de diferentes instrumentos financeiros - não reembolsáveis, reembolsáveis e de renda variável". De uma visão de patrocínio, adotada nas ações anteriores, praticadas desde 1995, especialmente por meio do edital público de seleção de projetos cinematográficos - o Edital de Cinema, e "afeita às ações de comunicação institucional do Banco" (BNDES, 2012), outra visão é adotada, norteada pelo desenvolvimento e fortalecimento da cadeia produtiva do setor audiovisual. Recentemente, para estender os financiamentos a outros nichos da economia da cultura, foi lançado o Programa BNDES para o Desenvolvimento da Economia da Cultura (BNDES/ PROCULT). Em 2009, o Banco foi contratado para operar diretamente no Programa Cinema Perto de Você, com recursos associados do FSA e do PROCULT. Com a promulgação da Lei 12.485 e com os novos recursos da CONDECINE, incumbe ao BNDES, desde dezembro de 2011, operar como agente financeiro central do FSA; de modo específico, cabe ao BNDES gerir os recursos destinados ao desenvolvimento de um mercado de conteúdos para televisão, cinema e outras mídias, previsto o repasse de $R \$ 2$ bilhões, até o exercício fiscal de 2015, a bancos de desenvolvimento, agências de fomento e/ou bancos públicos. Em maio de 2012, o Banco Regional de Desenvolvimento do Extremo Sul (BRDE) foi credenciado pelo CGFSA, e contratado pelo BNDES, para atuar como novo agente financeiro para as linhas de 


\section{Cinema e televisão: afastamentos e reaproximações na economia do audiovisual brasileiro contemporâneo}

produção e distribuição de obras para cinema e televisão. ${ }^{7}$ Esses desígnios realçam o reconhecimento do BNDES e do BRDE como importantes agentes econômicos, e mais, como agentes econômicos que transitam como agentes culturais no setor audiovisual.

Nova legislação, novo fundo público, novos recursos estão inseridos em um contexto de ampliação e sedimentação do mercado audiovisual brasileiro. Em 2011, as receitas desse mercado, centralizadas principalmente nas TVs Aberta e por Assinatura, correspondem a cerca de $\mathrm{R} \$ 33$ bilhões (PDM, 2012). Entre os segmentos do mercado em destaque, a TV por Assinatura apresenta a taxa de crescimento mais elevada. Dados da ANATEL registram que o ano de 2012 foi encerrado com mais de 16 milhões de assinaturas: de 4.583.125 de assinantes, em dezembro de 2006, o número foi elevado para 16.188.957 de assinantes em dezembro de 2012, estimado, ainda, um aumento de 35 milhões em um período de cinco anos. O gráfico a seguir mostra a referida evolução. Esses números acenam para um dos impactos das inovações mencionadas, e corroboram os altos índices de consumo de bens e serviços culturais realizado no ambiente doméstico brasileiro. Em dezembro de 2012, 222 mil adições líquidas são registradas, e 16,2 milhões de domicílios brasileiros com serviços de TV por Assinatura são contabilizados. Isso significa 3,4 milhões de novas assinaturas, em 2012, e um aumento de $27 \%$ na base de assinantes. De acordo com o Instituto Brasileiro de Geografia e Estatística (IBGE), considerado o número médio de 3,3 pessoas por domicílio, esses serviços são distribuídos para 53,4 milhões de brasileiros e estão presentes em mais de $27 \%$ dos domićlios. Apesar do crescimento desses serviços nas regiões Norte $(17,1 \%)$, Nordeste $(12,4 \%)$ e Centro-Oeste $(24,0 \%)$, a região Sudeste lidera em números, com a presença dos serviços em $38,6 \%$ dos domicílios (ANATEL, 2013).

\footnotetext{
${ }^{7}$ A Financiadora de Estudos e Projetos (FINEP), empresa pública vinculada ao Ministério de Ciência e Tecnologia (MCTI), responsável pelas chamadas públicas do FSA no período compreendido entre os anos de 2008 a 2010, e a Caixa Econômica Federal, responsável pela estruturação do Projeto Cinema da Cidade, inserido no Programa Cinema Perto de Você, são outros agentes financeiros do FSA, credenciados nos anos de 2007 e 2010, respectivamente.
} 
Tabela 8. Serviços de TV por Assinatura: 2006 - 2012.

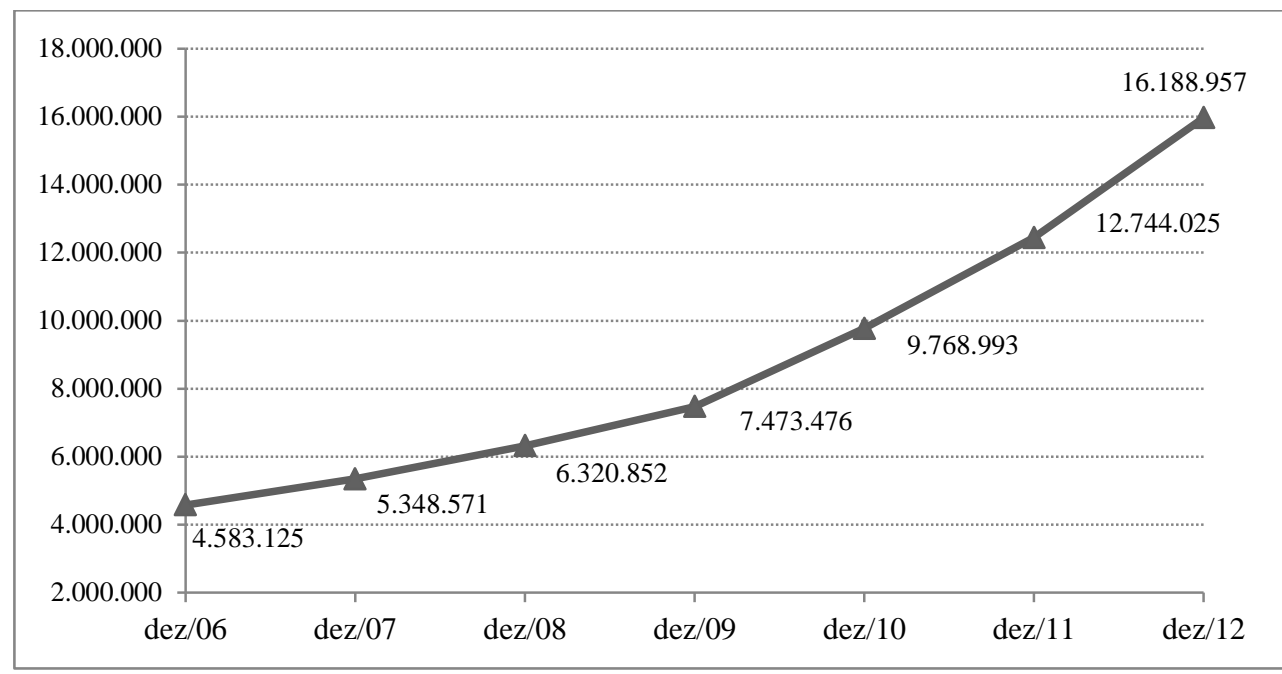

Fonte: ANATEL, 2013.

Ao unificar as normas da TV por Assinatura, a Lei 12.485 dispõe sobre a regulamentação das atividades de produção, programação, empacotamento e distribuição de conteúdo audiovisual no Serviço de Acesso Condicionado (SeAc). Compete à ANCINE e à ANATEL a regulamentação das normas infralegais, observadas as áreas de atuação de cada agência. A ANCINE, por meio das Instruções Normativas 100 e 101, de 29 de maio de 2012, objetos de audiências e consultas públicas, regulamenta as atividades de programação e de empacotamento; já a ANATEL, por meio de resoluções, regulamenta as atividades de distribuição. Além disso, a lei versa sobre a outorga de serviços de comunicação por assinatura para empresas de telecomunicações, com fins de reduzir barreiras quanto à entrada de novos prestadores e estimular a competição e a pluralidade. Atualmente, há 154 operadoras desses serviços no país, organizadas em 84 grupos econômicos. Em dezembro de 2012, o número de assinaturas do grupo econômico Net/Embratel corresponde a 8.494.999, seguida pelo número de assinaturas do grupo Sky/Directv que corresponde a 5.038.863. Aberto o mercado para novos agentes econômicos, novas disputas são esperadas. No próximo gráfico, são mostrados os números de assinaturas dos principais grupos econômicos que prestam esses serviços no Brasil. 


\section{Cinema e televisão: afastamentos e reaproximações na economia do audiovisual brasileiro contemporâneo}

\section{Gráfico 1. Distribuição das Assinaturas por Grupo Econômico: Dezembro de}

2012.

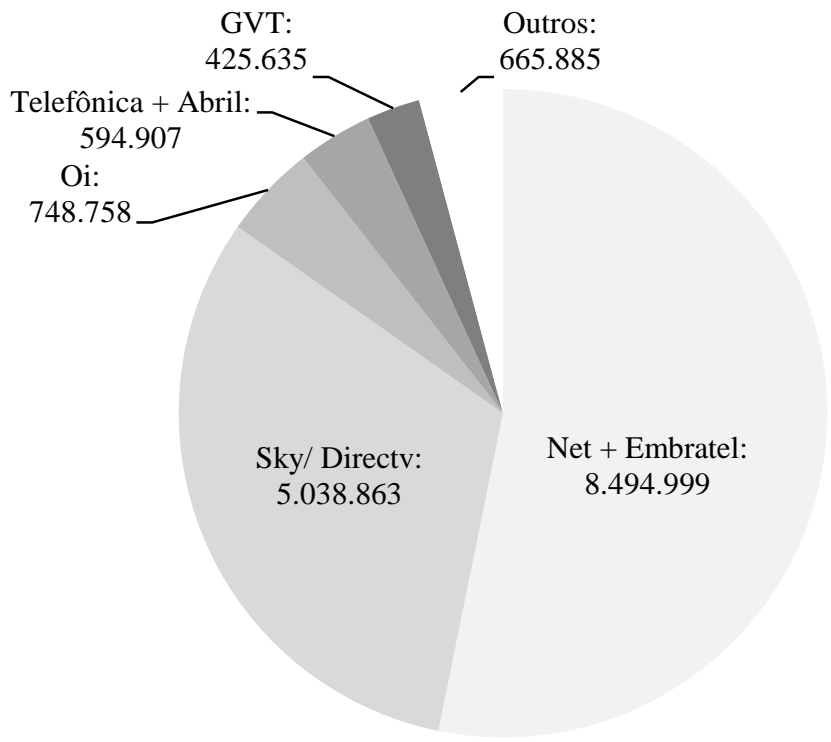

Fonte: ANATEL, 2013.

Esses serviços são prestados através do emprego de distintas tecnologias: por meios físicos confinados (Serviço de TV a Cabo - TVC); via espectro radioelétrico em micro-ondas (Serviço de Distribuição de Canais de Multiponto Multicanal MMDS - Multichannel Multipoint Distribution System); por meio de frequência UHF - Ultra High Frequency (Serviço Especial de Televisão por Assinatura - TVA); e via satélite (Serviço de Distribuição de Sinais de Televisão e de Áudio por Assinatura Via Satélite DTH - Direct to Home). Em conformidade com os dados da ANATEL, com o ingresso de concessionárias de telefonia no mercado de TV por Assinatura, esse último serviço alcança $60,8 \%$ das assinaturas em dezembro de 2012, e ultrapassa os serviços a cabo, que alcança 38,3\% no mesmo período. A ascensão da atividade audiovisual encontra respaldo em alguns eventos. Analisados os 20 canais de maior audiência nesses pacotes, 9 deles apresentam uma vasta programação de filmes e séries, sendo tal programação um dos principais motivos especificados pelos usuários para a assinatura desses serviços (PDM, 2012). Outrossim, há o aumento da renda da população, mais especificamente, há o crescimento da classe $C$ e a inserção dessa classe na sociedade de consumo. Outro evento, está relacionado com a propagação de serviços de telefonia móvel e de internet banda larga, assim como com a difusão de 
equipamentos e tecnologias como tablets, smartphones, e outras, que tecem novas possibilidades de formatos, modelos de negócio e distribuição de conteúdos audiovisuais (ANATEL, 2012).

A promulgação da Lei 12.485 , aliada ao credenciamento do BNDES para a gerência do FSA, produz uma expectativa de reorganização do mercado audiovisual, com uma maior abrangência de projetos, sobretudo independentes (Pfeiffer, 2012). Um modelo de negócios ancorado em uma integração vertical de produção, programação e provimento, com financiamentos publicitários, assinala a trajetória da televisão no país (Ortiz Ramos, 2004). De um lado, esse modelo apresenta a conquista da universalização dos serviços televisivos e, de outro, o distanciamento das produções independentes, o óbice ao ingresso de novos competidores, e a estagnação da TV por assinatura, somente em expansão nos tempos atuais. Nos pacotes de TV por Assinatura, os poucos canais disponíveis eram programados, até então, em grande parte, por grupos internacionais (PDM, 2012).

A partir da articulação entre o FSA e a Lei 12.485, programadoras nacionais adquirem espaço nesse mercado, e abrem espaço para produtoras em consolidação e já consolidadas como a O2 Filmes, entre outras. Fernando Meirelles, sócio da empresa citada, corrobora a informação, registrando o aumento imediato das demandas por conteúdos audiovisuais com a publicação da Lei da TV por Assinatura. ${ }^{8}$ Na mesma direção, Roberto Oliveira, diretor da TX Filmes, confirma que é nítido o aumento da demanda por conteúdo audiovisual, e assevera que a preparação de muitos canais para cobrir essa cota advém da promulgação já anunciada dessa legislação, durante a longa tramitação do projeto de lei. Marco Altberg, presidente da Associação Brasileira dos Produtores Independentes de TV (ABPI-TV), afirma que essas inovações conferem à produção independente "um valor dentro do mercado", e a elas são creditadas o aumento do número de produtoras associadas, de 170 para 265. Luiz Noronha, diretor-executivo de TV, da Conspiração Filmes, diz que os estímulos da nova lei se estendem, também, a investimentos nos próprios serviços. Como se vê, as produtoras falam em uma "explosão de demanda", ou até mesmo em uma "pequena revolução" .9

Uma das principais inovações trazidas pela Lei 12.485/11 é a obrigatoriedade de cotas de conteúdo brasileiro nas programações das TVs por Assinatura. Essa determinação envolve a veiculação de conteúdos nacionais - entendidos como aqueles produzidos por empresas brasileiras registradas na ANCINE, ou produzidos por essas empresas em associação ou coprodução com empresas de

${ }^{8}$ Disponível em http://www1.folha.uol.com.br/ilustrada/1101792-nova-lei-da-tv-paga-faraindustria-ser-mais-forte-diz-fernando-meirelles.shtml, acesso em dezembro de 2012.

Disponível em http://www1.folha.uol.com.br/mercado/1211461-cota-de-conteudonacional-estimula-producao-para-tv-e-cria-pequena-revolucao.shtml, acesso em janeiro de 2013. 


\section{Cinema e televisão: afastamentos e reaproximações na economia do audiovisual brasileiro contemporâneo}

outros países -, nos horários nobres ${ }^{10}$ dos canais de espaço qualificado ${ }^{11}$ da TV por assinatura, excetuados os canais da TV Aberta, canais esportivos, canais jornalísticos. Ainda, é previsto um aumento do número de canais nacionais nos pacotes por assinatura. Com a implementação dos dispositivos dessa lei, novas dinâmicas são estabelecidas para o campo audiovisual brasileiro, e distintos segmentos desse mercado podem ser contemplados. Similar sistema de cotas já vigora e resta consolidado nos países da Comunidade Europeia, no Canadá, na Austrália e na Coréia do Sul. Na esteira desses países, produtores de conteúdos e exportadores de formatos audiovisuais, a Lei 12.485 busca alçar o Brasil a essas mesmas condições. Essa política de veiculação de conteúdos nacionais $\mathrm{e}$ independentes e, mais, da oferta de canais nacionais nos pacotes da TV por assinatura, está sendo implementada de forma progressiva, e configura um importante meio para assentar espaços para a cultura brasileira nesse mercado.

A "revolução" desencadeada pelo FSA e pela Lei 12.485, aponta para a ampliação do mercado audiovisual brasileiro, e pode ser visualizada pelos primeiros impactos na dinâmica desses mercados, seja pelo aumento de demandas de conteúdos nacionais, seja pelo aumento de demandas de serviços de TV por Assinatura. Em um primeiro balanço da aplicação da Lei 12.485, realizado por Manoel Rangel no evento Rio Content Market, em janeiro de 2013, o diretorpresidente da ANCINE assevera que ao longo do ano de 2012, ocorreu um aumento significativo da presença de conteúdo brasileiro nos canais de TV por Assinatura e, para além disso, há uma "efervescência da atividade da produção, com incremento de receitas, de qualidade, de salários, entre outros; novos canais brasileiros nasceram disponibilizando mais conteúdo, e há ainda uma maior demanda por conteúdo brasileiro com mais canais comprando produções nacionais".

Também merece referência o crescimento do mercado de cinema em 2012, consoante balanço elaborado pela Superintendência de Acompanhamento de Mercado, e divulgado pela ANCINE. Em números, a arrecadação das salas de cinema atinge $\mathrm{R} \$ 1,6$ bilhão em 2012 , com um aumento de $12,13 \%$ em relação ao ano anterior. O público alcança 146,4 milhões, e a participação de público quanto aos filmes nacionais alcança $10,62 \%$, sendo $5,12 \%$ no primeiro semestre do ano, e $15,2 \%$ no segundo. No total, o público de filmes brasileiros corresponde a 15,5 milhões, e dos 83 filmes nacionais lançados comercialmente, cinco deles superam 1 milhão de espectadores. Estes cinco filmes, E aí, comeu?; Até que a sorte nos separe;

\footnotetext{
${ }^{10}$ Como prescreve a Instrução Normativa 100, da ANCINE, o horário nobre, nos canais direcionados para crianças e adolescentes, compreende o período das $11 \mathrm{~h}$ às $14 \mathrm{~h}$ e das $17 \mathrm{~h}$ às $21 \mathrm{~h}$; para os demais canais, o período das $18 \mathrm{~h}$ às $24 \mathrm{~h}$.

${ }^{11}$ De acordo com a Lei 12.485/2011, são aqueles canais que exibem, predominantemente, filmes, séries, animações, documentários, e similares.
} 
Gonzaga - De pai para filho; Os Penetras; e De Pernas pro Ar, foram contemplados e comercializados pelas Linhas de Ação do FSA. Além desses dados, outros podem ser destacados, como a expansão do parque exibidor e o aumento do número de salas destinadas a lançamento de filmes nacionais. De 48 salas, em 2011, o número é elevado para 63 salas, em 2012. Todos esses números indicam uma ocupação do cinema nacional no mercado cultural. Abaixo, segue um quadro com os dados relacionados ao mercado de cinema brasileiro, no período compreendido entre os anos de 2008 a 2012.

Tabela 9. Mercado de Cinema Brasileiro: 2008 - 2012.

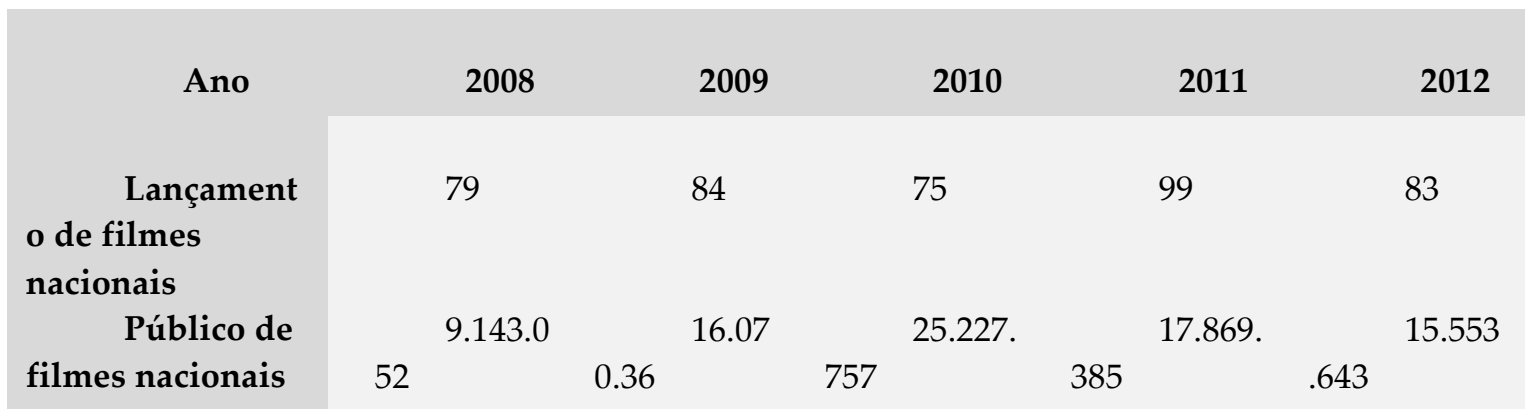

Fonte: Filme B, 2012; ANCINE, 2013.

Nesse texto, algumas nuances que conformam os traços da configuração contemporânea do mercado audiovisual no Brasil foram apresentadas e, a partir desses traços, uma reorganização dos negócios e dos mercados culturais é percebida. Nesse novo âmbito, assinalado pelo entrelaçamento entre cultura, desenvolvimento, criatividade e diversidade, o audiovisual pode ser considerado uma via para a afirmação das identidades e o reconhecimento das diferenças (ROSSINI, 2003). Valorização da cultura brasileira, incentivo para a produção e para a circulação de conteúdos audiovisuais nacionais, ampliação da oferta de serviços de TV por Assinatura e diminuição do preço final aos consumidores, geração de riqueza interna, consolidação do mercado audiovisual, possibilidade de crescimento de diversos segmentos desse mercado, são alguns demarcadores dessa nova configuração. Na luta mundial de conteúdos, uma batalha vem sendo travada 


\section{Cinema e televisão: afastamentos e reaproximações na economia do audiovisual brasileiro contemporâneo}

pelo controle da informação, pelo domínio dos formatos audiovisuais, pela conquista de novos mercados. Nessa batalha de mídias e culturas, o Brasil busca uma identidade em prol da diversidade cultural (MARTEL, 2012). O FSA e a Lei 12.485 são fios que tecem essa nova tessitura, em que os meios de audiovisuais buscam conviver e interagir uns com os outros (BABHIA, 2012, p. 206).

\section{Referências Bibliográficas}

ALVES, Elder Maia. A economia simbólica da cultura popular sertanejo-nordestina. Maceió: Edufal, 2011.

BAHIA, Lia. Discursos, políticas e ações: processos de industrialização do campo cinematográfico brasileiro. São Paulo: Itaú Cultural: Iluminuras, 2012.

BARBERO, Jesús Martín. Dos Meios às Mediações. Rio de Janeiro: UFRJ, 2003.

BEZERRA, Laura; ROCHA, Renata. Políticas de audiovisual. In: RUBIM, Antonio Albino Canelas; ROCHA, Renata (Orgs.). Políticas Culturais. Salvador: Edufba, 2012.

BOURDIEU, Pierre. A economia das trocas simbólicas. São Paulo: Perspectiva, 1992.

BUTCHER, Pedro. O cinema brasileiro hoje. São Paulo: Publifolha, 2005. . A dona da história. Dissertação de Mestrado defendida na UFRJ em 2006.

CANCLINI, Néstor Garcia. Culturas híbridas: Estrategias para entrar y salir de la modernidad. México: Grijalbo, 1990.

Consumidores e cidadãos. Rio de Janeiro: Editora Ufrj, 2001.

CASTELLS, Manuel. A sociedade em rede. São Paulo: Paz e Terra, 1999.

DELEUZE, Gilles. Conversações. Rio de Janeiro: Editora 34, 1992.

FORNAZARI, Fábio Kobol. Instituições do Estado e políticas de regulação e incentivo ao cinema no Brasil: $\mathrm{O}$ caso da ANCINE e Ancinav. RAP, Vol. 40, p. 647677, 2006.

IKEDA, Marcelo. Lei da ANCINE comentada (Medida Provisória 2.228-1/01). Rio de Janeiro: WSET Multimídia, 2012.

JENKINS, Henry. Cultura da Convergência. São Paulo: Aleph, 2008.

KELLNER, Douglas. A cultura da mídia. Bauru: Edusc, 2001.

LIPOVETSKY, Gilles; SERROY, Jean. A tela global: Mídias culturais e cinema na era hipermoderna. Porto Alegre: Sulina, 2009.

MATTA, João Paulo Rodrigues. Políticas públicas federais de apoio à indústria cinematográfica: Um histórico de ineficácia na distribuição. In: MELEIRO, Alessandra (Org.). Cinema e mercado. Vol. III. São Paulo: Escrituras Editora, 2010.

MARSON, Melina Izar. Cinema e Políticas de Estado: da Embrafilme à ANCINE. São Paulo: Escrituras Editora, 2009.

MATTELART. Armand. Diversidade cultural e mundialização. São Paulo: Parábola, 2005. 
Gárdia Rodrigues Silva

MARTEL, Frédéric. Mainstream: A guerra global das mídias e das culturas. Rio de Janeiro: Civilização Brasileira, 2012.

ORTIZ, Renato. Mundialização da cultura. São Paulo: Brasiliense, 2003.

ORTIZ RAMOS, José Mario. Cinema, televisão e publicidade: Cultura popular de massa no Brasil dos anos 197-1980. São Paulo: Annablume, 2004.

PFEIFFER, Daniela. Coordenadora de Projetos da Associação Brasileira de Produtores Independentes de Televisão (ABPI-TV). Entrevista à autora, em 2012.

REIS, Ana Carla Fonseca. Economia criativa como estratégia de desenvolvimento: Uma visão dos países em desenvolvimento. São Paulo: Itaú Cultural, 2008.

ROSSINI, Miriam de Souza. Dois olhares sobre a identidade latino americana. IN: ADAMI, Antonio; HELLER, Barbara; CARDOSO, Haydée Dourado de Faria (Orgs.). Mídia, Cultura, Comunicação 2. São Paulo: Arte e Ciência, 2003, p.173-183.

\subsection{Sítios Eletrônicos Consultados}

http://www.abpitv.com.br http://www.anatel.gov.br http://www.ancine.gov.br http://www.bndes.gov.br http://www.culturaemercado.com.br http://www.cultura.gov.br/site http://www.filmeb.com.br http://www1.folha.uol.com.br/ http://www.planalto.gov.br http://www.pnud.org.br http://www.tcu.gov.br http://www.unesco.org 